system in plasma membranes of rat liver. I. Properties. J. Biol. Chem., 246: 1849 (1971).

14. Rodbell, M., Lin, M. C., Salomon, Y., Londos, C., Harwood, J. P., Martin, B. R., Rendell, M., and Berman, M.: Role of adenine and guanine nucleotides in the activity and response of adenylate cyclase systems to hormones: Evidence for multisite transition states. Advan. Cyclic Nucl. Res., 5: 3 (1975).

15. Salomon, Y., Londos, C., and Rodbell, M.: A highly sensitive adenylate cyclase assay. Anal. Biochem., 58: 541 (1974).

16. Salomon, Y., and Rodbell, M.: Evidence for specific binding sites for guanine nucleotides in adipocyte and hepatocyte plasma membranes; A difference in fate of GTP and guanosine $5^{\prime}$ - $(\beta, \gamma$-imino)triphosphate J. Biol. Chem., 250: 7245 (1975).

17. Sobel, B. E., and Mayer, S. E.: Cyclic adenosine monophosphate and cardiac contractility. Circ, Res., 32: 407 (1973).

18. Vinicor, F., Clark, J. F., and Clark, C. M., Jr.: Development of hormone receptors in the isolated fetal heart. In: R. A. Camerini-Dávalos and H. A.

Copyright $\odot 1976$ International Pediatric Research Foundation, Inc.
Cole: Early Diabetes in Early Life, p. 105. Ed.:(Academic Press, New York, 1975)

19. Charles River Breeding Laboratories, Wilmington, Mass.

20. Worthington Biochemical Company, Freehold, N.J.

21. Sigma Chemical Company, St. Louis, Mo.

22. ICN Pharmaceutical, Inc., Waltham, Mass.

23. New England Nuclear, Boston, Mass.

24. Gift of Dr. William Bromer, Eli Lilly Company.

25. The authors are indebted to Miss Carol Grime for her careful preparation of this manuscript.

26. This investigation was supported by a grant from the American Heart Association and Veterans Administration Research funds.

27. Requests for reprints should be addressed to: C. M. Clark, Jr., M.D., Veterans Administration Hospital, 1481 West Tenth St., Indianapolis, Ind. 46202 (USA).

28. Accepted for publication May 14, 1976

Pediat. Res. 10: 854-856 (1976)

Bilirubin

hyperbilirubinemia

newborn

Printed in U.S.A.

\title{
Riboflavin and Bilirubin Response during Phototherapy
}

\author{
JAMES A. PASCALE, LEROY C. MIMS, ${ }^{(17)}$ MARTIN H. GREENBERG, DAVID S. GOODEN, AND
}

ELIZABETH CHRONISTER

The William K. Warren Medical Research Center and Saint Francis Hospital, Tulsa, Oklahoma, USA

\section{Extract}

Twenty-four jaundiced neonates were studied, 12 in the treatment group and 12 in the untreated group. Patients were randomly selected to receive oral riboflavin. The mean 24-hr bilirubin decrease was determined during phototherapy. Blue light $(420-470 \mathrm{~mm})$ energy ranged from $6-10 \mu \mathrm{W} / \mathrm{cm}^{2}$. The observed 24-hr bilirubin decrease was compared with the expected decrease based on an energy-dose-response relationship. Riboflavin-treated infants received either 6-7 $\mu \mathrm{W} / \mathrm{cm}^{2}$ blue light energy or 8-10 $\mu \mathrm{W} / \mathrm{cm}^{2}$ (same as control group). Those infants receiving less energy than the control group $\left(8-10 \mu \mathrm{W} / \mathrm{cm}^{2}\right)$ had a mean 24 -hr bilirubin decrease $(3.05 \mathrm{mg} / 100 \mathrm{ml} / 24 \mathrm{hr})$ equal to the control group $(3.09 \mathrm{mg} / 100$ $\mathrm{ml} / \mathbf{2 4} \mathrm{hr}$ ). Those riboflavin-treated infants receiving energy equal to the control group showed a greater decline $(5.2 \mathrm{mg} / 100 \mathrm{ml} / 24 \mathrm{hr})$ in their mean 24-hr bilirubin. Although effective, additional in vivo studies are required to clarify the full effects, especially on DNA, of using photosensitizers such as riboflavin in the presence of bilirubin and blue light energy $(420-470 \mathrm{~nm})$.

\section{Speculation}

Riboflavin may become an important adjunct to phototherapy for neonatal hyperbilirubinemia. As a producer of singlet oxygen it is capable of transferring enough energy to overcome the oxygen quenching effect of bilirubin in its rapid degradation.

Riboflavin (6',7-dimethyl-9-(D-1'-ribityl) isoalloxazine is an essential dietary constituent for mammals (9). The mono- or dinucleotide form functions as the prosthetic group of a number of important enzymes. Flavin mononucleotide, riboflavin 5'-phosphate is formed from riboflavin and ATP catalyzed by flavokinase. Further addition of ATP with the mononucleotide forms $\mathrm{PP}_{\mathrm{i}}$ and FAD, an important nucleotide and coenzyme in cellular respiration. All biologic functions of riboflavin appear to be limited to its contribution to the synthesis of these two coenzymes. In man, ingested riboflavin is excreted largely unchanged or as riboflavin 5'-phosphate (FMN).

Recent in vitro (7) and in vivo (4) evidence indicates that riboflavin enhances the photodecomposition of bilirubin. Application of this principle to phototherapy for neonatal hyperbilirubinemia using blue light energy in a predictable doseresponse relationship (5) forms the basis for this report.

\section{MATERIALS AND METHODS}

All infants studied were at term (38-40 weeks) and predominantly Caucasian. Assignment to the study was made only after the infants were committed to phototherapy for hyperbilirubinemia by their private pediatricians $(10)$.

Study subjects included 24 infants born at St. Francis Hospital, Tulsa, Oklahoma. There were 12 males and 12 females. Hyperbilirubinemia was defined as a serum bilirubin concentration greater than $9 \mathrm{mg} / 100 \mathrm{ml}$ and phototherapy was initiated at or above this level (range 9-18 mg/100 ml). Blue light energy was administered and measured as described in a previous report (5). Serum bilirubin was collected and measured. All infants studied had developmental (physiologic) jaundice with no laboratory or clinical evidence of illness or hemolytic process. A system of random numerical selection was used to determine which patients 
were to receive riboflavin. The treated group received oral riboflavin as the sodium phosphate (10) $1.5 \mathrm{mg} / \mathrm{kg}$ every $12 \mathrm{hr}$. Riboflavin therapy was begun $6 \mathrm{hr}$ before phototherapy and was discontinued after the first $24 \mathrm{hr}$ of light treatment. Both treated and control groups were fed a prepared formula $(20 \mathrm{cal} / \mathrm{oz})$ every 3-4 $\mathrm{hr}$. The mean riboflavin per $24 \mathrm{hr}$ administered in the formula was calculated as $0.3 \mathrm{mg} /$ infant.

\section{RESULTS}

Table 1 describes the characteristics of the patients in the three study groups. One-half of the riboflavin-treated infants received approximately $50 \%$ less blue light irradiance (5) than the contro group and yet had a similar mean 24-hr bilirubin decrease. On the other hand, the riboflavin-treated group that received irradiance equal to that of the control group had a $2.1 \mathrm{mg} / 100 \mathrm{ml}$ greater reduction in serum bilirubin over a similar time period.

The observed mean 24-hr bilirubin decrease for all three study groups was plotted against the predicted $24-\mathrm{hr}$ decrease based on the time-dose response curve (5) (Fig. 1). The control group results were as predicted.

No recognizable complications resulted from this study.

\section{DISCUSSION}

Riboflavin metabolism in the newborn infant has received very little attention $(1,3)$, particularly in regard to the association of riboflavin and phototherapy. Recently Kostenbauder and Sanvor-

Table 1. Characteristics of study groups (mean $\pm S D)$

\begin{tabular}{|c|c|c|c|c|c|}
\hline Study group & $\begin{array}{l}\text { No. of } \\
\text { patients }\end{array}$ & $\begin{array}{l}\text { Light } \\
\text { irradi- } \\
\text { ance, }{ }^{1} \\
\mu \mathrm{W} / \mathrm{cm}^{2}\end{array}$ & Weight, $\mathrm{g}$ & $\begin{array}{c}\text { Age at } \\
\text { onset of } \\
\text { therapy, } \mathrm{hr}\end{array}$ & $\begin{array}{c}24-\mathrm{hr}^{2} \\
\text { bilirubin } \\
\text { decrease, } \\
\mathrm{mg} / 100 \mathrm{ml}\end{array}$ \\
\hline$I$ (untreated) & 12 & $8-10$ & $\begin{array}{c}3,124 \\
( \pm 449.8)\end{array}$ & $\begin{array}{r}70 \\
( \pm 24)\end{array}$ & $\begin{array}{c}3.09 \\
( \pm 0.79)\end{array}$ \\
\hline 2 (treated) & 6 & $6-7$ & $\begin{array}{c}3,123 \\
( \pm 464.81)\end{array}$ & $\begin{array}{c}82 \\
( \pm 27)\end{array}$ & $\begin{array}{r}3.05 \\
( \pm 0.60)\end{array}$ \\
\hline 3 (treated) & 6 & $8-10$ & $\begin{array}{c}3,367 \\
( \pm 303.2)\end{array}$ & $\begin{array}{c}63 \\
( \pm 21.6)\end{array}$ & $\begin{array}{c}5.2 \\
( \pm 1.1)\end{array}$ \\
\hline
\end{tabular}

${ }^{1}$ Characteristics of light measuring device: peak sensitivity $460 \mathrm{~nm}$; half-maximal sensitivities 385 and $507 \mathrm{~nm}$.

${ }^{2}$ Decrease observed during the first $24 \mathrm{hr}$ of phototherapy. deker $(4,7)$ suggested that riboflavin may be an important adjunct to phototherapy in lowering serum bilirubin levels in newborn infants. They suggested that riboflavin, a sensitizer, absorbs light energy in the presence of oxygen and becomes excited to a higher energy state (triplet form). This energy in the form of singlet oxygen is then transferred to bilirubin, also a sensitizer, which then reacts with the singlet oxygen to undergo photodecomposition.

During the course of the study presented herein, two important papers came to our attention. One of these (8) reported that riboflavin in the presence of light altered one of the base moieties of purified DNA with minimal cleavage of the phosphodiester linkages. A similar effect was noted in living human HeLa cells. The authors suggested that such mutational changes in the DNA structure could occur which may have carcinogenic potential. Speck's group (8), however, did not study the effects on DNA of riboflavin and phototherapy in the presence of bilirubin. Meanwhile, Foote et al. (2) studied the kinetics of bilirubin photo-oxidation in relation to singlet oxygen. They concluded that although bilirubin quenched singlet oxygen faster than it reacted with it, it was still one of the most reactive known receptors of singlet oxygen. They also observed that riboflavin was a very potent sensitizer, thus generating considerable singlet oxygen when exposed to light. They suggested that since riboflavin did not react and thus photodegrade, it could surely result in severe tissue photodynamic damage.

Riboflavin being the "super" sensitizer, it might be expected to generate singlet oxygen at a rate greater than bilirubin was able to quench, thus accounting for a greater reactive phenomenon and greater photodegradation. Likewise, it would seem plausible to expect less singlet oxygen attack on DNA structure if indeed the bilirubin molecule was available as an acceptor molecule for the high energy oxygen. In support of this hypothesis is our observation of no increase in red blood cell hemolysis which one might expect if excessive singlet oxygen were being produced by the photoexcited riboflavin over and above that accepted by available bilirubin (6).

Data herein suggest that riboflavin given as a dietary supplement can enhance the reduction of serum bilirubin in newborn infants receiving phototherapy. The data also confirm early work (5) that the 24-hr bilirubin response is predictable based upon the energy received from the visible spectral band between 420 and 470 $\mathrm{nm}$.

In view of the recent in vitro observations on the effect of phototherapy on DNA in the presence of riboflavin, however, we cannot recommend its use during phototherapy. We urge further in vitro and animal study to ascertain the safety of using riboflavin as an adjunct to phototherapy in human infants.

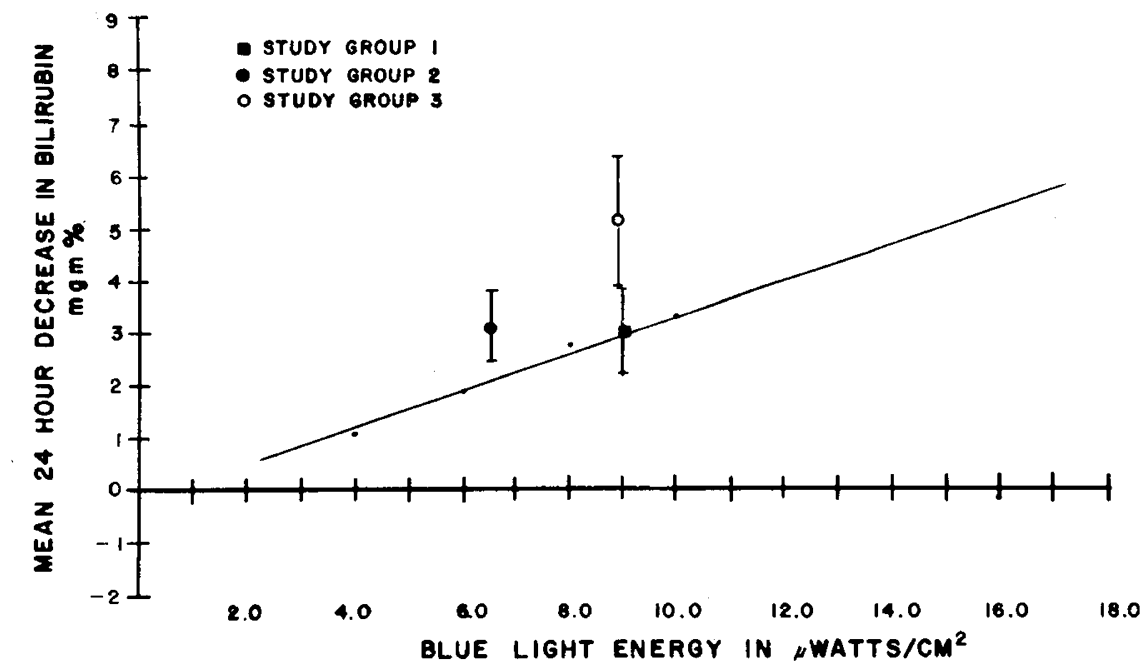

Fig. 1. The mean bilirubin decrease (milligrams per $100 \mathrm{ml}$ ) of each study group during the first $24 \mathrm{hr}$ of phototherapy plotted against irradiance (micro-Watts per $\mathrm{cm}^{2}$ ) and superimposed on the predicted time-dose response curve previously published (5). 


\section{SUMMARY}

The influence riboflavin had on bilirubin response to phototherapy was studied in 24 newborn infants, 12 in the treated group and 12 in the untreated group. Those patients receiving riboflavin showed a $50 \%$ greater mean bilirubin decrease during the first 24 $\mathrm{hr}$ of phototherapy when compared to patients receiving no riboflavin, but the same quantum of blue light energy.

\section{REFERENCES AND NOTES}

1. Clarke, H. C.: Relationship between whole blood riboflavin levels in mothers and in the prenate. Amer. J. Obstet. Gynec., 3: 43 (1971).

2. Foote, C. S., and Ching, T.-C.: Chemistry of singlet oxygen. XXI. Kinetics of bilirubin photooxygenation. J. Amer. Chem. Soc., 97: 6209 (1975).

3. Jusko, W. S., Khanna, N., Levy, G., Stern, L., and Yaffe, S. J.: Riboflavin absorption and excretion in the neonate. Pediatrics, 45: 945 (1970).

4. Kostenbauder, H. B., and Sanvordeker, D. R.: Riboflavin enhancement of bilirubin photocatabolism in vivo. Experientia, 29: 282 (1973).

5. Mims, L. C., Estrada, M., Gooden, D. S., Caldwell, W. R., and Kotas, R. V.: Phototherapy for neonatal hyperbilirubinemia-A dose:response relationship J. Pediat., 83: 658 (1973).
6. Odell, G. B., Brown, R. S., and Kopelman, A. E.: J. Pediat., 81: 473 (1972).

7. Sanvordeker, D. R., and Kostenbauder, H. B.: Mechanism for riboflavin enhancement of bilirubin photodecomposition in vitro. J. Pharmacol. Sci., 63: 404 (1974).

8. Speck, W. T., Chang, C. C., and Rosencranz, H. S.: In vitro studies of effects of light and riboflavin on DNA and HeLa cells. Pediat. Res., 9: 150 (1975).

9. West, E. S. Todd, W. R., Mason, H. S. and Van Bruggen, J. T.: Textbook of Biochemistry, 4th Ed. (MacMillan, New York, 1966).

10. O'Neal, Jones, and Feldman, Inc., St. Louis, Mo.

11. Parental and private physician consent was obtained to study these patients.

12. This research was supported by a grant from The William K. Warren Medical Research Center, Tulsa, Oklahoma

13. James A. Pascale, M.D., is a Meade Johnson Nutrition Research Fellow in Neonatal-Perinatal Medicine, Saint Francis Hospital and The William K. Warren Medical Research Center, Tulsa, Oklahoma

14. Martin H. Greenberg, M.D., is chairman, Department of Neonatal Medicine, Saint Francis Hospital, Tulsa, Oklahoma.

15. David S. Gooden, Ph.D., is Director, Radiation Physics, Natalie Warren Bryant Cancer Center, Saint Francis Hospital, Tulsa, Oklahoma.

16. Elizabeth Chronister, R.N., is Research Nurse, The William K. Warren Medical Research Center, Tulsa, Oklahoma.

17. Requests for reprints should be addressed to: LeRoy C. Mims, M.D., Department of Pediatrics, University of Arkansas Medical Center, 4301 West Markham, Little Rock, Ark. 72201 (USA).

18. Accepted for publication May 14, 1976

\title{
Introduction of Dr. Clement A. Smith for the John Howland Award
}

\author{
(From the American Pediatric Society, April 28, 1976, St. Louis, Missouri)
}

\author{
MARY ELLEN AVERY
}

Children's Hospital Medical Center, Boston, Massachusetts, USA

Dr. Smith, members of the Smith family, friends of Dr. Smith, and admirers-that must include everyone in this room-

Surely one of the greatest pleasures that can befall a "student" is the opportunity to share with others perceptions of a favorite "teacher" (Fig. 1). This pleasure is mine today, as I attempt to bring you some feeling for Clement Smith and his extraordinary accomplishments.

To many he conveys the wisdom of the lover of nature, and seems more a Vermonter (his adopted land) than the midwesterner he is. Born 74 years ago in Ann Arbor, Michigan, the son of Shirley Smith, Professor of English and later Vice President of the University of Michigan, and Sara Smith, he was the second son in a household of four children. He remained in Ann Arbor for all of his formal education, including a Master's degree in English as well as the M.D. degree. His literary interests are well known to most of you, who recall his distinguished editorship of Pediatrics for the 11 years from 1962 to 1973, his book, Physiology of the Newborn Infant, recently published in a fourth edition with his former student and coeditor Dr. Nick Nelson, and the series of articles on medical writing in the American Journal of Diseases of Children. Perhaps less well known is his familiarity with the poetry of several centuries, including much of that written by Robert Frost. The friendship with Robert Frost dated from Frost's stay as Poet in Residence in Ann Arbor and subsequently flourished in Cambridge. The friendship or kinship with the great poets of history is fostered by Palgrave's Golden Treasury, Dr. Smith's constant companion.

The medical years began in Ann Arbor, where he received his M.D. from the University of Michigan in 1928. His first 2 years as a house officer were in the University Hospital in Ann Arbor, but in 1931 he came to the Children's Hospital, Boston, in the era of Drs. Kenneth Blackfan, James Gamble, and James Wilson. Any of you who have had the privilege of knowing Dr. Smith realize the extent to which the friendships of those years have influenced his subsequent life. One sometimes wonders if the Children's Hospital ever had a Chief Resident other than James Wilson. Dr. Smith returned to Ann Arbor as Instructor in Pediatrics but only briefly, when Harvard again beckoned him to come in the role of Assistant Physician to the Children's Hospital. He was at first in charge of the Tuberculosis Clinic and an Attending Physician, but his eyes roamed across the street on occasion to the Lying-In, where he became particularly fascinated by the problems of young infants. In 1937 Dr. Stewart Clifford invited him to take a more major role 